\title{
Biochemical aspects of interaction between jasmine and blister mite, Aceria jasmini Chan
}

\author{
R. VISHNUPRIYA*, G. UMAPATHY, K. RAMARAJU, P. MALARVIZHI ${ }^{1}$ AND V. MANIVANAN ${ }^{2}$ \\ Department of Agricultural Entomology, Tamil Nadu Agricultural University, Coimbatore (T.N.) INDIA \\ ${ }^{1}$ Department of Soil Science and Agricultural Chemistry, Tamil Nadu Agricultural University, Coimbatore (T.N.) INDIA \\ ${ }^{2}$ Department of Agronomy, Tamil Nadu Agricultural University, Coimbatore (T.N.) INDIA
}

\section{ARITCLE INFO}

Received : 09.01 .2016

Revised : 23.02 .2016

Accepted : 05.03 .2016

\section{KEY WORDS :}

Jasmine blister mite, Aceria jasmini,

Biochemical changes, Leaves

*Corresponding author:

Email: vishnupriyaento@gmail.com

\section{ABSTRACT}

The Jasmine blister mite, Aceria jasmini Chan. is a serious eriophyid mite infesting jasmine commercially grown in many parts of South India. Due to feeding by this mite results in formation of blister like erineal patches on the jasmine leaves. Irregular patches of cottony white erineal mats seen both on adaxial and abaxial surface of the leaves supports hundred of white coloured worm- like mites. Biochemical investigations carried out in the susceptible Long and Pointed Budded variety revealed that there was nonsignificant increase in moisture content, decrease in chlorophyll, total sugars, reducing sugars, significant increase in total free amino acids, phenols, crude protein content and peroxidase activity. Among the nutrients tested, nitrogen, phosphorus and potassium contents increased, while non-significant decrease in calcium and magnesium, whereas significant decrease in iron, manganese, copper and zinc were noticed due to mite feeding.

How to view point the article : Vishnupriya, R., Umapathy, G., Ramaraju, K., Malarvizhi, P. and Manivanan, V. (2016). Biochemical aspects of interaction between jasmine and blister mite, Aceria jasmini Chan. Internat. J. Plant Protec., 9(1) : 172-176. 